International Journal of Social Science And Human Research

ISSN(print): 2644-0679, ISSN(online): 2644-0695

Volume 04 Issue 05 May 2021

DOI: 10.47191/ijsshr/v4-i5-15, Impact factor-5.586

Page No : 989-997

\title{
Historical Perspective of Gender Typed Participation in the Performing Arts in Sri Lanka During the Pre- Colonial, The Colonial Era, and the Post- Colonial Eras
}

\author{
Dr. Winojith Sanjeewa
}

\begin{abstract}
When the Sri Lankan performing art was analysed, a clear-cut difference in gender-typed participation in dancing, singing, playing music, and the traditional rituals (such as Shanthi karma) can be identified. Furthermore, this research has found that gender roles in performance have evolved through time. It can be seen how the existence of -Hindu- Buddhist practices from Vijayaâ $€^{\mathbf{T M}_{S}}$ arrival to Sri Lanka in 543 BCE to the period of Portuguese who conquered Sri Lanka in 1505 CE takes a new facet in the colonial period and the post-colonial period blending with the European concepts. It can be analysed as follows, First, the changes occurred in masculinity, femininity, or the concepts of Tandava, and Lasya, then the rituals relating to concepts of Divinity in the pre-colonial period, then the changing constructs and perspectives regarding gender performances in the colonial period and the gender shifts and gender synthesis in the post-colonial period.
\end{abstract}

\subsection{INTRODUCTION}

This Paper will primarily question how the concept of gender affects the artiste and his/her art and ethno-religious cohesion in Sri Lanka. In the first section the concepts of masculinity and femininity in western art and the concepts of lasya and tandava in eastern art is discussed. Then, a historical perspective is provided on gender-typed participation during the pre-colonial, colonial and postcolonial eras. For the purpose of this research, the performing artiste and the art form are divided into three eras. The first era considered is the period from the arrival of Vijaya in 543 BCE up to the subjugation of Sri Lanka by the Portuguese in 1505. This period is identified as the pre- colonial era. The period between 1505 CE up to 1948, when Sri Lanka became independent of British rule, is referred to as the colonial era. The period subsequent to 1948 is identified as the post-colonial era. Therefore, the three eras of pre-colonial, colonial, and post-colonial are used as a time framework to examine the changes and evolution of performing arts and the artiste in this research particularly in relation to gender. This will provide an understanding of gender as it relates to Sri Lankan Buddhist and Hindu art and the artiste. To undertake more in-depth research about the themes that arose from the literature review, an ethnographic methodology was adopted to collect data. For the collection of this research data, many collection methods such as observation, participant observation, interviews, focus groups, documentary evidence, and oral history, were employed. Emic, or insider, as well as etic, or outsider, perspectives were helpful for me to identify and analyse data obtained through several means. Thus, I was able to collect and interpret the data as an insider and also as an outsider which can be a feature of "Ethnographic Research" (see Wolcott, 2005; Pole and Morrison, 2003; Hammersley and Atkinson, 2007; Atkinson et al, 2001; Arya, 2017; Sanjeewa, 2018).

The research process involved field work totalling nearly five months in Sri Lankan Buddhist and Hindu temples and engaging in creative activities connected with the performing arts. Powder maker, referring to field work, points out, "Field work is the study of people and of their culture in their natural habitat" (Powdermaker, 1968:418). I explored several aspects of the performing artiste in different settings, namely, traditional dance, drumming, teacher lineages, traditional kalayatana, traditional rituals, live performances, and Buddhist and Hindu ritual practices.

My pilot study in relation to the Buddhist monuments was undertaken in Anuradhapura and Polonnaruva, and monuments in Tamil and Muslim cities of the north east such as Jaffna, Batticaloa, and Trincomallee. Two main factors were considered in selecting these locations. First, Anuradhapura and Polonnaruva were the first hydro-civilisations in Sri Lanka, and the sculpture, carvings and paintings relevant to the performing arts in sacred places with links to Buddhism and Hinduism running back over two thousand years were available in these locations. Second, the selection of main towns in the northern and eastern provinces, such as Jaffna, Trincommalee and Batticaloa, was because they are inhabited mainly by the Tamil-Hindu community, and many Hindu historical, sacred places and the performance of singing, music, and dance are found in these provinces. 
Historical Perspective of Gender Typed Participation in the Performing Arts in Sri Lanka During the Pre- Colonial, The Colonial Era, and the Post- Colonial Eras

\subsection{Masculinity, Femininity and Tandava, Lasya}

There are many new expressions in the field of gender studies such as gender bias, gender difference, gender discrimination, gender identity (Butler, 1990; Senelick, 1992; Colebrook, 2004). The researchers who examine masculinity and femininity give various interpretations and there seems to be no consensus; as Senelick argues, "whatever biological imperative may order sexual differentiation, whatever linguistic patterns may undergird it, it is outward behaviour that calibrates the long scale of masculinity and femininity in social relations" (Senelick, 1992: IX). Therefore, gender connected with masculinity and femininity is a "way of referring to the social organisation of the relationship between the sexes" (Scott, 1996: 1053). The social-rooted connection is discussed by Stets and Burke who argue that femininity and masculinity are rooted in the social (one's gender) rather than in the biological (one's sex). Similarly, "societal members decide what being male or female means (e.g. dominant or passive, brave or emotional), and males will generally respond by defining themselves as masculine while females will generally define themselves as feminine". However, as Stets and Burke argue, "Because these are social definitions, however, it is possible for one to be female and see herself as masculine or male and see himself as feminine" (Stets and Burke, 2000:997). Therefore, it is important to inquire how far this social organisation between the sexes as pointed out by Scott is applicable to art and the use of art by the artiste. The gender of the artiste determines the opportunity of engaging in ritual performance, the opportunity to visit the religious places where such rituals are held and the opportunity to train in dance and music in the performing arts. Therefore, this chapter first examines the gender power operative within the masculinity and femininity of the Sri Lankan performing artiste.

The concepts of masculinity and femininity discussed in relation to gender in the western world are seen also in the eastern world when discussing the performing arts. Important among them are the concepts of Lasya, and tandava (Vatsyayan, 1967; Sharma, 2015; Reed, 2010). Particularly in the Indian dance tradition the word tandava is used for masculinity and the word Lasya for femininity. These Lasya and tandava concepts, are discussed by Reed in relation to the Sri Lankan performing arts.

Dances performed in the tandava style are vigorous, bold, and heroic, while dances performed in the lasya style are graceful, gentle, and tender. In general, dancers in contemporary Sri Lanka equate tandava with "masculine" and lasya with "feminine", and among stage performers it is widely assumed that men should dance in the tandava style and women in the lasya style (Reed, 2010: 35).

So as Reed points out, male Sri Lankan artistes in their ves dance ${ }^{1}$, dahaatasanni $^{2}$, devol $^{3}$, and telme ${ }^{4}$ in the upcountry, low country ${ }^{5}$ and Sabaragamu ${ }^{6}$ traditions, present a vigorous, bold and heroic tandava dance while the female artistes present a graceful, gentle and tender dance through folk dances such as $k_{u l u^{7}}$, kalagedi ${ }^{8}$, and $\mathrm{raban}^{9}$. In Sri Lankan society a woman is always regarded as a symbol of gentleness. According to the SelalihiniSandesa $a^{10}$ composed by the Buddhist monk Sri Rahula Thera in the fifteenth century, the dancing girl is described as a quiet gentle creature shaken like a lamp-flame by the wind:

Flickering lamp-flames they seem these dancers in array,

\footnotetext{
${ }^{1}$ Describing the vesbandima and the initiation ceremony of the dancer and his ves costume Reed observes, "Traditionally, dancers were not permitted to wear the full vescostume until they had completed several years of training and had undergone the ceremony of the dancer's initiation, known as vesbandima or tying of the ves" (Reed, 2010:42). This process of vesbandima happens only among male artiste mainly because it is a process considered sacred and free from kili(impurity).

${ }^{2}$ The dahaatasanniya in the low country tradition deals with eighteen kinds of diseases and their cures. Several methods similar to those used in western science such as psychotherapy, grouptherapy, Gestalttherapy, psychodrama and hypnotherapy seem to be operative within this healing ceremony

${ }^{3}$ This is the main healing ceremony performed for fertility in the southern dance tradition centred on God Devol, God Kataragama, and Goddess Pattini.

${ }^{4}$ This is the pure traditional and rhythmical dance from the low country.

${ }^{5}$ The low country dance tradition is the other Sri Lankan dance tradition that is deeply bound with Sinhalese-Buddhist rituals. The low country dance tradition which is considered to be a main tradition of the classical dance traditions of Sri Lanka (Reed, 2010:10; Nurnberger, 1998: XXXIII; Suraweera, 2009:2; Dissanayake, 1994:123) is prevalent in the southern and western provinces of Sri Lanka (Suraweera, 2009:1; Dissanayake, 1989:123; Reed, 2010:11).

${ }^{6}$ The Sabaragamu dance tradition, which is considered to be one of the main Sri Lankan dance traditions (Reed, 2010; Nurnberger, 1998; Dissanayake, 1993; Delgoda, 1959).

${ }^{7}$ This is the winnowing fan used to separate the chaff from the grain.

${ }^{8}$ Pot dance.

${ }^{9}$ The frame drum with a circumference of 10, 14 inches is called rabana. There are several kinds of frame drums and the athrabana (hand drum) can be played by hand and the drum with a circumference of 30-50 inches is placed on a stand and the players sit around it and play it.

${ }^{10}$ This (or the Messenger poem) is a unique form of poetry in Sinhalese literature. The poem is used to send a message to a god or king through birds such as swans, parrots, cuckoos, doves, and peacocks. The description of cities, women, and temples is described in detail and the poems help to gain knowledge of contemporary society.
} 
On whose broad hips hang the heavy waist folds that ripple and flare,

Who shoot sidelong glances at their arms as they rise, and they fall,

Transfigured their forms in the glare that beats from their jewels,

(Holt, 2011:1280)

In particular, the woman engaging in dance is seen as a 'beauty' as an interviewee explained:

When a woman dances it's a beautiful sight. When a woman dances she has quite a different rhythm and movement than when a man dances. The spectator enjoys the gracefulness of the woman. ${ }^{11}$

Thus, it seems that when a woman dances, it is her responsibility to see that she is graceful, gentle and tender (Reed, 2010: 35).

\subsection{Historical perspective of gender typed participation in the performing arts}

In this section, the discussion firstly focuses on how the concepts of divinity and masculinity, as presented by the performing artiste in the pre-colonial era, evolved during colonialism and after independence. Attention is also paid to how the performing arts freed themselves from the concepts of divinity and masculinity in the colonial era and allied themselves with the concepts of femininity and sexualisation and how, by the post-colonial era, without being divided into 'masculine' or 'feminine', they integrated with gender negotiation.

\subsubsection{Pre-Colonial Era: Divinity and Ritual Performer}

What is evident when studying the use of gender within the performing arts during the pre-colonial era is that the male artiste becomes a 'divine icon' as a matter of course. In this transformation, as a 'divine icon' there forms a natural bond between the masculine identity and power. This is evident particularly in paintings and sculpture of the Anuradhapura (377 BCE-1017 CE) and Polonnaruva (1017 CE -1255 CE) periods depicting figures of dancing, singing, and instrument-playing individuals. Here the artiste is depicted as a well-built, strong person and as a masculine icon with a bare upper body. These visual art sources in the early period depict the artiste mostly as a male figure. These male figures become ideal models of masculinity with divine status within the visual representation. The costumes and gestures are depicted in such a manner as to suggest a king or a deity. This masculinity and divine status are more clearly visible in the costumes used by the Kandyan dancer ${ }^{12}$. Primarily, the costume is made to resemble that of the king born of a flower in the kohombākankāri ${ }^{13}$ ritual.

The archetypal Kandyan dancer is a male dancer adorned in the spectacular Kankariya dress known as the ves costume. The costume consists of a gleaming silver head dress decked with shimmering boleaves, silver armbands and anklets, a beaded harness, and a lower garment of voluminous white cloth overlaid with a wide, ornamented belt. The ornaments of the ritual dancer (yakdessa), especially the ritual crown (vestattuva), were traditionally the most important symbols of a dancer's status as a skilled ritual performer. The ornaments of the ves costume are considered to be half of those worn by the healer king Malaya, whose curing of the ancient Sri Lankan king Panduvas in the fifth century BCE is the culmination of the Myth of the Kankariya (Reed, 2010: 11-12).

Thus, not only in kankari rituals but also in visual arts originating from the Anuradhapura (377 BCE -1017 CE) and Polonnaruva (1055 CE -1255 CE) periods, the divine icon of the artiste attired in costumes and ornaments as described above is depicted and a sense of majesty is presented representing the unique power enjoyed by kingship. This divine status belonging to the ves costume designed to suit a masculine body is clearly seen in the verses (sahali) sung when deities are invited to attend the audience (aileyadeema) during the kohombākankāri ritual, namely the suggestion that the deity lives in every place of that costume, and is therefore all-powerful:

This invitation is to the deity living in the golden headdress of His Royal Highness King Male; this invitation is to the deity living in the golden sikhabandana of his Royal Highness; this invitation is to the deity living in the golden nettimala of His Royal Highness; this invitation is to the deity living in the golden payimpata of His Royal Highness. ${ }^{14}$

However, there seems to be a difference in depicting the femininity and divinity of the female performing artiste in literary sources. The main reason for depicting the woman in literary sources in the Anuradhapura, Polonnaruva periods and later in the Dambadeniya, Gampola, Kotte and Kandy may have been the attraction that the woman's gentleness provides. A Professor in Sinhalese who discussed this aspect pointed out:

\footnotetext{
${ }^{12}$ Kandyan dance or "upcountry dance" (Reed, 2010:10; Nurnberger,1998: XXIII; Sederaman,1962:5; Dissanayake,1994:35), which is one tradition of the Sri Lankan dance traditions, is the dance form prevalent in the area called upcountry of Sri Lanka, namely Mahanuwara, Udunuwara, Yatinuwara, Sat Korale, SataraKorale, Dumbara and Harispattuwa (Dissanayake, 1994:35). ${ }^{13}$ The main healing ceremony in the upcountry dance tradition, this is considered to have been used to cure King Panduvasudeva (504-474 BCE) of a disease called divi dosha. This healing ceremony performed by dancers in the ves costume with drummers is now held to invoke the god of fertility.

${ }^{14}$ Kohombā Kankāriya ritual ( PER/KOH/ANU/01/2015)
} 
Not only in Sinhalese literature but also in world literature the woman becomes a main theme in poetry, novel, song and the cinema. The main reason is that the woman is a symbol of beauty or her breasts, hips, and face are symbols of sexuality. So, the woman performing artiste rather than the male artiste is given preference in literature such as Sandesa poetry, and chronicles. $^{15}$

Descriptions of the performing arts and the artiste in Dipavamsa, Mahāvamsaand Sandesapoems (messenger poems) seem to express the emergence of femininity replete with the emotion of sexual love (srangara) instead of a masculine, divine icon. The dancing girls in the SalalihiniSandesaare described as follows:

Stand and gaze at the dancing girls in the dance arena,

Whose hair knots are bound with scented confusion of flowers full-blown,

Their pretty ears decked with shining gold leaves;

Their long, dark eyes painted with finely made salve.

Flickering lamp- flames they seem these dancers in array,

On whose broad hips hang the heavy waist folds that ripple and flare,

Who shoot sidelong glances at their arms as they rise, and they fall.

Transfigured their forms in the glare that beats from their jewels.

Drinking in the charms of these women who dance,

Stamping feet of lotus to beaten-out rhythms

To swing the girdles that are swathed around their lovely wide flanks,

And their anklets hung with bells that wake into sound.

(Holt, 2011:128)

The author of the Kokila Sandesatoo expresses a view like that of the author of SalalihiniSandesa, who describes the dancing girls as extremely beautiful. Accordingly, the author of the Kokila Sandesadescribes the breasts of dancing girls as:

Bandimin sudupata rasinada nava sandavan nalale

Salasinranrasunennadadevaminpakamale

Anga ran tana tatamin leladee ina mini mevule

Angan dena ranga dutu kanam situ noele

(Gunawardena, 1962 :244).

Here the poet describes the breasts of dancing girls as kinihiri ${ }^{16}$ flower buds, their necks garlanded with fragrant jasmine, moving hands decked with golden bracelets rhythmically, moving their feet decked with tinkling bells and wonders who will not be fascinated by them. So, instead of the male body imposed with divinity in the visual arts there emerges through literary sources the female body replete with srangara(love or beauty). More information is revealed about the female performing artiste in the Sandesapoetry and the chronicles. Many Sandesapoets have described how the elegance of the female body suits the act of dancing. One of the interviewees for this research describing this tendency pointed out that:

In any case, the female body is rather more appropriate in literary description than the male figure. Their eyes, eyebrows, lips, breasts, and hips attract literary imagination. Creative writing always prefers the description of female gracefulness rather than the robust male figure. The other important factor is that all these works have been written by male authors. So, it is not a matter for surprise that they tended to describe the opposite gender. Thus, it is seen that the use of gender of the artiste depends on the gender of the person who creates the relevant works of art. ${ }^{17}$

Therefore, it is seen that in the case of dance, music and singing portrayals in literary sources give attention primarily to the female body. Thus, the gracefulness of woman in the performing arts in the respective periods seems to have stimulated the poet in his creations. The other notable feature is that these female artistes directly contribute to Buddhist religious rituals. As Buddhism rejects caste, divine concepts and that the woman is 'polluted' because she menstruates, women participated freely and directly in rituals performed in Buddhist temples. A clear illustration of this is the description in the Mahāvamsaof King Dutthagamini attending the Buddhist religious ceremony launching the MahaThupa accompanied by dancing girls:

The king supported, in order of their rank, by many ministers, richly clothed as befitted their office, surrounded by many dancers richly clothed like to celestial nymphs (Geiger,1912: 192-193).

Both Mahāvamsaand Dipavamsa describing Buddhist religious rituals point out on several occasions that those female performing artistes directly took part in some religious rituals. However, no evidence is available that female performing artistes took part in such rituals as KohombāKankāriya. This appears to have been due to the issue of kili (impurity) which is connected with females.

\footnotetext{
${ }^{15}$ Interview ( INT/SL/PER /03/M1)

${ }^{16}$ Scientific name : Cochlospermumreligiosum (Pandhure et al., 2013). Kinihiri or 2 . the tropical region of South Asia.

${ }^{17}$ Interview (INT/SL/COL/05/M1)
} 

The Colonial Era, and the Post- Colonial Eras

It may be presumed that the idea of kili was not considered in Buddhist religious activities which did not involve the worship of deities. One of the interviewees describing the male and female contribution in the performing arts, as depicted in archaeological evidence, thought that the non-participation of women was due mainly to the concept of 'impurity' mentioned above and the contemporary male-centred social system. He stated:

What is seen mostly in the Buddhist and Hindu temples in the Anuradhapura and Polonnaruva periods are the male, strong bodies with bare upper bodies. The main reason for this may have been kingship and male-centred social environment. With the concept of 'purity' in religious places, it may be that the males were given pride of place. The other reason is that the strength needed for dancing and singing was portrayed through the male body in painting and sculpture ${ }^{18}$.

It may, therefore, be argued that during the pre-colonial era, the idea of 'purity' was a decisive factor in the participation of women in the performing arts. The reason for this may be the relationship with religious rituals involving the worship of deities.

The evidence available in archaeological and literary sources about both female and male performing artistes during the pre-colonial era takes diverse forms. In archaeological evidence of carvings, paintings, and sculpture the subject is mostly male, and it appears that the reason may be the idea of divinity being identified with man and maleness. However, by the Polonnaruva period (1055 CE $-1255 \mathrm{CE}$ ), this trend seems to have undergone a change. In visual art sources, there are many examples of female artistes inspired by Indian dance traditions and its methods. The South Indian influence after the Polonnaruva kingdom (1055 CE -1255 CE) seems to have influenced the emergence of the concept of femininity in art. Because of the South Indian Tamil, Chola, Pallava and Hindu religious and ethnic influence, the Devadās $\bar{l}^{19}$ dance tradition in the Hindu culture seems to have found a place within the Sri Lankan arts. In most of the carvings, paintings and sculpture found after the Polonnaruva period (1055 CE -1255 CE), graceful female performing artiste could be seen instead of the robust male performing artiste. This is clearly illustrated in the eth pahana(elephant lamp) of Dedigama, the figures in the Mihinthaletemple paintings in the Mulkirigalatemple , carvings in the Yapahuwa palace , and the carvings in the moulding of the Gadaladeniya temple (Sanjeewa,2006. These paintings, carvings and sculpture clearly show that the Devadāsiconcept to Hinduism that becomes established at the end of the Anuradhapura period and the Polonnaruva period had an impact on their art and changed it.

\subsubsection{Colonial artiste: changing constructs and perspectives}

The divine and masculine concept related to the male artiste and the religious rituals related to the female artiste seemed to undergo a change during the colonial period. When investigating the gender representation in the performing arts during the colonial era, several significant factors were identified. The first is that the concept of femininity comes to the fore during the Portuguese, Dutch and British administrations, over the concept of masculinity as represented in the visual arts.In paintings, carvings and sculpture completed in the Portuguese as well as the Dutch periods, the female performing artiste is given pride of place including the western female performing artiste, which is amply demonstrated by their costumes, bodily complexion and dance styles. Several factors seemed to have caused this change

The European romantic ideal that spread in the 1800s began to be reflected in art and literature and it had its impact on colonial administrations like Sri Lanka. What happened was that before the feminine qualities that were invested within the romantic ideal, the masculine ego was undermined. ${ }^{20}$

It is seen that the "ego"21 of the masculine performing arts is undermined during the colonial era and the females increasingly participated in religious rituals and performances on the public stage. According to literary sources on art during the Kandyan kingdom (1594 CE-1815 CE), women participated in dancing. Certain contemporary reports by overseas visitors throw light on this female representation seen in the visual arts. The Dutch visitor Spillbergen comments, beautiful girls dance pleasingly in the Kandy Perahera. Their upper body was bare, and the under body was covered with decked cloth (De Villiers, 1906). Knox, expressing a view similar to this, points out that women had to go naked from their waist upwards and that their dress must end above the knee (Knox, 1681:67). So, during the Dutch and British rule increasing numbers of women participated in the performing arts. So, by the end of the colonial era male-centred visual representation is seen gradually transmuting into the representation of the female body. Although much information is found in literary sources ${ }^{22}$ about the female artiste and her practice of art, there seem to be some differences in the practical performance of art in society. Reed points out that the woman faced several challenges in dance performance. It is the question of 'honour' that the female performer faces: "Prior to the 1940s, Sinhala women with the exception

\footnotetext{
${ }^{18}$ Interview (INT/SL/COL/05/M1)

${ }^{19}$ The name refers to women who have dedicated their entire life to worship and service in Hindu Devālaya(Deity shrine). in southern as well as western India. They join the Devālaya when they are between the ages of 8 and 15 and they perform religious rituals, please the elite and engage in traditional Bharata natyam and odissi.

${ }^{20}$ Interview (INT/SL/COL/05/M1)

${ }^{21}$ Interview (INT/SL/COL/05/M1)

${ }^{22}$ Dipavamsa, Mahāvaṃsa and sandesa poems
} 

The Colonial Era, and the Post- Colonial Eras

of the performer of diggenatun did not dance. Dancing as a profession was considered immoral, 'a trade fit for harlots"' (Reed, 2010:198).

In colonial Sri Lankan society where dancing by women was looked down upon as prostitution the performing arts seem to have been entirely male dominated. Nurnberger points out that the female artiste Vajira ${ }^{23}$ together with Chitrasena ${ }^{24}$ pioneered a change in this situation, and she adds "She became the first fully professional female dancer of the Sinhalese dance, above all of the Kandyan style, at a time when the traditional dance forms of the Island were dominated exclusively by male" (Nurnberger, 1998:137). A view like Nurnberger's about the male dominant dance tradition and the female performing artiste was also expressed by one of the interviewees:

Although the female dancer's body is attractively depicted in murals, sculpture and literature it never became a reality in practice. I joined on my own because I like to dance. One thing is that we belong to the goigama caste and so we are forbidden to dance. The other thing is I am a woman. That also prevents me from dancing. At the start, it was not easy to overcome both these obstacles. About 65 years ago, when I left the stage after a performance, I was shouted at as a 'harlot.' The day I got married, my aunt told my husband to check whether I was a virgin. I very well remember her telling, "how do we know what has happened to her while dancing in those groups"? ${ }^{25}$

The discrimination suffered by the female performing artistes in the colonial period as pointed out by this interviewee seems to have continued up to the present day.

During the three colonial periods, women of the Sinhalese-Tamil society seemed to enter the field of art slowly but surely (Reed, 2010). The main reason for this change was the British missionary education established in Sri Lankan society. With the opportunity for education without gender discrimination, women too could participate in the traditional arts. Even after independence from British rule, the Sinhalese-Buddhist government continued this system of education without gender discrimination and selected women for posts in the field of education, which provided the opportunity for women to engage in the practice of art. Because of the introduction of dance into schools in the 1940s and 1950s women have become an increasingly visible presence in the dance world, and the vast majority of dance students who aspire to become professional dance teachers are female, as Reed points out. (Reed, 2010: 198). Therefore, the traditional, male-centred kankari dance frees itself from the conservative perspective and finds a place in school concerts, private dance classes, governmental ceremonials, religious and secular processions, weddings and Buddhist temples (Reed, 2010:198). Hence, by the second half of the British colonial era male dominance in the traditional arts seems to have moved towards female artistes and the female dominance within the performing arts emerged.

\subsubsection{The gender shift, gender synthesis and the post-colonial performing artiste}

There are many important features in studying the performing arts and the artiste during the post-colonial era. The main feature with regards to gender is the breaking down of the conventional views on women and their direct participation in the performing arts. During the post-colonial era, while women asserted their dominance in the field of art there also arose social criticism against them in the sense that "Virginity is highly valued and unmarried women who live alone or away from their families arouse immense anxiety" (Reed, 2010:200).

So, the woman coming out of the conventional framework and participating in the arts amounted according to some sections of society, to her losing her virginity:

A woman dancing in those days meant wilful destruction of her character. It amounted to the demolition of accepted Sri Lankan tradition. It's a disgrace not only to oneself but also to the entire generation. ${ }^{26}$

This became a key aspect of social criticism and it continues up to the present day as was illustrated in the comments of a person I interviewed. Of six women artistes who participated in the focus group five agreed with this view but one put forward a different view:

In society different opinions are held not only on women but on all matters. We cannot say one particular opinion is right. It's only a certain group who claim that women's character is spoilt by dancing. But they have forgotten that in our civilization women had been dancing since the Anuradhapura and Polonnaruva periods and that kings espoused it. So, it's a lie to say that women didn't dance because of such fairy-tale views. Women do dance since the past up to present times. Virginity is there to prove one's purity to one's husband, not to make a public exhibition. ${ }^{27}$

\footnotetext{
${ }^{23}$ Vajira Dias, the spouse of Chitrasena, who for the first time broke the ban and opened for women and girls the domain of the dance (Nurnberger, 1998:97).

${ }^{24}$ Chitrasena is the most important founder of the modern Sinhalese stage dance theatre and the founder of the first totally professional school of dance -The Chitrasena school (Nurnberger, 1998:119).

${ }^{25}$ Interview (INT/SL/COL/03/FM1)

${ }^{26}$ Interview (INT/SL/COL/03/FM1)

${ }^{27}$ Interview (INt/SL/COL/03/FM5)
} 

The Colonial Era, and the Post- Colonial Eras

Accordingly, there is apparently no consensus in society on the female artiste and her virginity. Reed points out that even by the 1990s the opinion of dancing women was not favourable. She argues that the taboo on wearing the traditional ves costume by women and taking part in the KohombāKankāriyathat was prevalent in the 1980s continued up to the 1990s and women participating in KuveniAsna ${ }^{28}$ and other kankari rituals was frowned upon by the artistes of the Berava ${ }^{29}$ caste (Reed, 2010: 201). In addition to the bringing of traditional kankari items onto the stage, the establishment of a powerful feminine performing arts tradition was an indirect result that took place during the post-colonial era.

This is seen in the colonial period, when the female dance artistes such as Chandralekha ${ }^{30}$, and Vajira enthusiastically brought onto the stage a new art full of traditional feminine items instead of the ballroom dancing that was confined to the English-speaking women of the elite. Nurnberger is of the view that Chandralekha is the best example of this trend:

She had the courage altogether to break through the gender barriers, which barred the Sinhalese women from dance performance in front of the greater public. Ladies of her social class used to do ballroom dancing in the European style in Colombo, but stage dancing and Sinhalese ritual dancing styles were worlds apart in their social acceptability (Nurnberger, 1998:138).

The opportunity arose for women to create new forms of art to suit themselves while dances like the Puja Natuma and Yuga Natuma cast women in submissive and domestic roles that conformed to notions of the conventional feminine ideal (Reed, 2010:204). The post-colonial female artiste seems to have created a new trend to replace the traditional art. This tendency in the performing arts caused a clash between "modest womanhood" and the traditional "image of woman" and as Reed observes, "As they expand their spheres of influence within the field of dance, women must constantly negotiate their practice in relation to ideas of respectability and ritual purity" (Reed, 2010: 200). It is through this tendency that Chandralekha, Cecilia Kotelawala and VajiraChitrasena pioneered the continuance of Sri Lankan up country dance, which was indeed a revolution in the Sri Lankan performing arts. They were able to maintain social acceptability and attract women from the urban and middle-class sectors. Nurnberger comments, "under the guidance of Chitrasena, (Vajira) grew up to be the founder and the first female interpreter of female style, that of the lasya of the Sinhalese up-country dance form (Nurnberger, 1998: 137). Therefore, it is seen that women directly engaged in the performing arts and contributed towards it, which up to then had been male-dominated. An important fact discernible here is that female performing artistes are used in advertising as a sexual object through the media:

With the arrival of the television, woman's body has become a commercial article that supplies sexual satisfaction. In such trade advertisements, where the woman's body is displayed, her breasts, hips, etc. are highlighted. And through that the female dancer becomes willy-nilly an article in the sex market with a price. ${ }^{31}$

Therefore, it is seen that the female dancer inevitably becomes, through the modern media, a source that provides pleasure and sensuality. Because of the sexualisation of the dance through leisure culture, the practising female dancer receives a high price. Within this consumer culture the female body acquires a new cultural meaning and this "new interpretation" seems to be becoming established within Sri Lankan society:

Now concert organisers always ask me for the same kind of items. 'The item where the girls danced wearing short sleeve jackets and short skirt.' 'The song sung by those beautiful girls.' 'I would like if you would give us the dance with the dress for belly dance style. ${ }^{32}$

So, the market seems to be attracted by the female body. How sexualisation has replaced the traditional female image can be seen in the frequent performances of salsa, ballroom and Bollywood dance, on the modern stage instead of the traditional upcountry, low country and Sabaragamu traditions. The description of ballroom dancing in western society as described by Rust that it is a "socially licensed sublimated promiscuity" (Rust, 1969: 125) and is seen in the case of Sri Lankan dance too:

The dance that was performed in the past seeking blessings of god has now become a sexual activity. In night clubs or dinner dances the female dance sells for a high price. There is very high competition. Which dance group enjoys the highest popularity among men? Who are the female dancers most suitable for clubs and night shows? Although this trend cannot be justified within Sri Lankan culture, it is unofficially accepted as a socially recognised phenomenon. ${ }^{33}$

\footnotetext{
${ }^{28}$ This refers to the dance item based on the singing in KuveniAsna, which is the main story in the upcountry kohombākankāri healing ceremony. The artiste dance with a coconut-shell lamp in the left hand and a stick to stoke the lamp's flame in the right hand, and the entire item takes over one hour.

${ }^{29}$ The term 'Berava' is used to refer to the caste called Berava, and the artiste are known by the term Beravayo.

${ }^{30}$ The first female dancer who performed the Sinhalese dances on the stage,was J.D.A Perera with the stage name of Chandra

Lekha (Nurnberger, 1998:121).

${ }^{31}$ Interview (INT/SRI/NUG 01/FM1)

32 Interview (INT/SRI/NUG 01/FM1)

33 Interview (INT/SRI/NUG 05/M1)
} 

The Colonial Era, and the Post- Colonial Eras

But we must not forget the female artiste who contribute to this new performing trend while at the same time preserving the traditional art form. There are those who participate in upcountry, low country and Sabaragamu traditions and preserve traditional dance through schools, universities and kalayatanas ${ }^{34}$ while at the same time preserving the female image. According to Reed this art "has given women wide scope for interpretation and transformation" (Reed, 2010: 21). Hence, women have succeeded in performing the dances in the madu ceremonies, which were up to then limited to men, showing that there were skills that they too could perform, and they have also become the Guru (teacher) who transmits that skill. This paves the way to attract learned, middleclass women of high caste to engage in the art, which was up to then limited to those of the Berava caste. Through this process, women now play a key role in the dance and through the mass media, have become a visual sexual icon.

An important fact regarding art in the post-colonial period is its sexualisation. An art with sexual orientation has come into existence replacing the traditional art, and "in the 1980s and 1990s some dances by women and by mixed-gender groups were becoming increasingly more sexual in their movements, costuming, and the themes' (Reed, 2010:212). The art that swiftly became sexualised was not confined to one gender, but both genders seem to have contributed towards the process:

There is a price for everything in the market. The price is determined on the value and the demand for it. Why does my performance receive a higher place in society? Look at the children in my dance group. They, both males and females, engage daily in body building exercises. They are boys and girls with beautiful bodies. Both groups put on make-up when they get on the stage. Both groups are attractive. I do my choreography to highlight their gracefulness. In short, I try to bring both groups on the stage in a sexy appearance. Actually, the demand is for this sexiness. ${ }^{35}$

Reed's description of this sexualisation in the Sri Lankan arts is significant, showing how far the traditional art has been sexualised. Reed points out those scholars of performance have noted while the number of women artistes has increased during the period, the sexualisation of dance often accompanies the transition from ritual to stage (Reed, 2010: 213).

The other important aspect of this sexualisation process is the emergence of the respective art as a positive factor in marriage. This is an aspect common to both Sinhalese and Tamil art. Describing the arangetram (the debut performance) of Bharatanatyam ${ }^{36}$ connected with the Tamil ethnic group, one of the interviewees a Bharata female dancer, observed:

The young woman who comes on the stage adorned with beautiful ornaments and catchy make-up looks truly like a goddess. The dance is appealing. Parents with young sons who attend these arangetram bring marriage proposals to her. The reason is that in our culture one qualification for marriage is the competence in this dance. So, the arangetram is, in a way, like offering her skills before the marriage market. Quite often, the wealthiest young man becomes her husband. ${ }^{37}$

This feature is clearly seen not only in Tamil-Hindu Bharatanatyam but also in Sinhalese-Buddhist art. Discussing this in relation to the marriage market, Reed describes the kalaelimagallaya (debut dance) as an occasion to announce a girl's availability and to display her for marriage (Reed, 2010: 212).Hence, art became freed within the colonial era from its ritual framework and came onto the modern stage as a popular form of art and it became a feature of the newly created marriage market.

\subsection{Conclusion}

In summary, during the pre-colonial era, the male artiste represented masculinity and divinity while the female artiste participated solely in religious rituals. This system changed during the colonial era with the shifting of the ritual art, which was up to then a male monopoly, to the females. This ritual art underwent several changes during the post-colonial era. A distinct feature of this change was that the ritual dance that was confined only to the males was now performed on the modern stage by females. Thus, it is seen that the male-dominant ritual art directly shifted towards the females. With this shift the women's contribution to the performing arts became further established and art also became sexualised. Within this sexualisation, the most important factor is how art had become a positive factor within the marriage market. Although there are several features noticeable about females, in the case of males it takes a different form. Particularly on the modern stage the contribution of the female artiste seems to have increased with the concomitant, social pressure on the male artiste deriving mainly from the 'homosexual' label attached to him. Thus, the masculine and divinity concept that was manifest during the pre-colonial era has changed into a system of sexualisation bound with femininity by the post-colonial period.

\section{REFERENCES}

1) Arya, R. (2017) 'Inter-generational perspectives on caste: a Hindu Punjabi study'. Contemporary South Asia, 25 (3), pp.285-300.

2) Atkinson, P., Coffey, A., Delamont, S., Lofland, J., and Lofland, L. ed. (2001) Hand book of ethnography. London, Sage.

\footnotetext{
${ }^{34} \mathrm{An}$ institution maintained by the teachers of hereditary art schools for the dissemination of the arts.

35 Interview (INT/SL/COL/06/M)

${ }^{36}$ Recognised as one of the Indian traditional dance forms (Reed, 2010; Nurnberger, 1998;Devi, 1998; Satkumaratnam, 2009; O'Shea,2007; Gaston, 1996), researchers point out that it has developed from a female-centred temple dancing tradition known as Devadāsī (Satkumaratnam, 2009:11; Katrak, 2011:26; Devi, 1998: 442).

${ }^{37}$ Interview (INT/SL/BAT /01/FM)
} 
Historical Perspective of Gender Typed Participation in the Performing Arts in Sri Lanka During the Pre- Colonial, The Colonial Era, and the Post- Colonial Eras

3) Butler, J. (1990) Gender trouble. New York, Routledge.

4) Colebrook, C. (2004) Gender. Basingstoke, Palgrave Macmillan.

5) De Villiers,J.A.J.(1906) The East And West Indian Mirror: Being An Account Of Joris Van Speilbergen's Voyage Round The World 1614-1617 And The Australian Navigations Of Jacob Le Maire. London, Hakluyt Society.

6) Delgoda, E, A. (1959) Sabaragamunatyakalawa [Sabaragamu Dance]. Colombo, Department of Cultural Affairs.

7) Devi, R. (1998) 'Bharata Natyam'. In: Cohen, S.J. ed. International Encyclopedia of Dance. Oxford, Oxford University Press, pp. 442-443.

8) Dissanayaka, M. (1994) Sinhala narthanakalawa [Sinhala dance]. Colombo, Godage Publishers.

9) Gaston, A.M. (1996) Bharata natyam: From temple to theatre. New Delhi, Manohar.

10) Geiger, W. (1912) Mahavamsa: Great Chronicle of Ceylon. Trans. London, Pali Text Society.

11) Gunawardana, V.D.S. (1962) Kokila Sandeshaya [The Koel's Message]. Colombo, S. Godage\& Brothers.

12) Hammersley, M., Atkinson, P. (2007) Ethnography: Principles in practice. London, Routledge.

13) Holt, J.C. ed (2011) The Sri Lanka reader. Durham and London, Duke University Press.

14) Katrak, H.K. (2011) Contemporary Indian Dance: New creative choreography in India and the diaspora. London, Palgrave Macmiillan.

15) Knox, R. (1681) An Historical relation of the island Ceylon in the East Indies. London, Richard Chiswell.

16) Nurnberger, M. (1998) Dance is the language of the gods: The Chitrasena school and the traditional roots of Sri Lankan stage dance. Amsterdam, VU University Press.

17) O'Shea, J.M. (2007) At home in the world: Bharatanatyam and on the global stage. Middleton, Wesleyan University Press.

18) Pandhure, N., Prasad, P., Biradar, S.R. (2013) 'Micro propagation studies in cochlospermumreligiosum'.International journal of advancements in research \& technology, 2 (6), pp. 263-270.

19) Pole, C., Morrison, M. (2003) Ethnography for education. Berkshire, Open University Press.

20) Reed, S.A. (2010) Dance and the nation: Performance, ritual, and politics in Sri Lanka. Wisconsin, The University of Wisconsin Press.

21) Rust, F. (1969) Dance in society. London, Routledge.

22) Sanjeewa, W. (2006) Lankeyanarthanaya ha wadanaya [The study of Sri Lankan dance and instrumental music as portrayed in Sri Lankan visual arts]. Colombo, Godage Publishers.

23) Sanjeewa, W. (2018) The performing artistes in Sri Lanka: the contribution to ethno-religious cohesion through their shaping and challenging of socio-cultural norms. PhD thesis, University of Leeds.

24) Satkumaratnam, A. (2009) Moving bodies, navigating conflict: Practicing bharatanatyam in Colombo, Sri Lanka. PhD Thesis Thesis, University of California Riverside.

25) Scott, J.W. (1996) 'Gender: A useful category of historical analysis'. The American Historical Review, 90 (5), pp.10531075.

26) Senelick, L. ed. (1992) Gender in performance: The presentation of difference in the performing arts. Hanover, University Press of New England.

27) Sharma, M.S. (2015) 'Ardhanarishvara magnified in the secret of the Nagas'. International journal of English language, literature and humanities, 2 (10), pp.185-189

28) Stets, J.E., Burke, P.J. (2000) 'Femininity/Masculinity'. In: Borgatta,E.F., Montgomery, R.J.V. ed. Encyclopedia of sociology. New York, Macmillan, pp. 997-1005.

29) Suraweera, S. (2009) Sri Lankan, low-country, ritual drumming: The Raigama tradition. PhD Thesis, University of Canterbury.

30) Vatsyayan, K. (1967) 'The theory and technique of classical Indian dancing'. ArtibusAsiae, 29 (2/3), pp.229-238.

31) Wolcott, H.F. (2005) Ethnography a way of seeing. Plymouth, Altamira. 